\title{
The Role of Red Algae in Abrupt Appearance of Animals in the Early Cambrian on Siberian Platform
}

\section{P. N. Kolosov}

Diamond and Recious Metal Geology Institute, SB RAS, Yakutsk, Russia.

Email: p_kolosov@diamond.ysn.ru

Received October $4^{\text {th }}, 2013$; revised November $21^{\text {st }}, 2013$; accepted December $12^{\text {th }}, 2013$

Copyright (C) 2013 P. N. Kolosov. This is an open access article distributed under the Creative Commons Attribution License, which permits unrestricted use, distribution, and reproduction in any medium, provided the original work is properly cited.

\begin{abstract}
Calcified rock-forming marine filamented benthic micro- and macrophytes of Dzhelindia Kolosov, 1970 (Figure 1(a)) and Chaptchaica Kolosov, 1975 (Figure 1(b)) genera, thrived in Neoproterozoic (1000 - 541 million years ago) Siberia together with cyanobacteria. Their belonging to Rhodophyta is well-grounded. These and other Neoproterozoic rodofits, as well as Epiphyton Bornemann 1886 (Figure 1(c)) and other Early Cambrian (541 - 513 million years ago) benthic algae, oxygenating floor of epicontinental sea basin, formed conditions, favorable for the animals. In combination with other biotic, and such abiotic factors as: equatorial position and tectonic feature of Siberian platform; volcanism; transgression of the sea; diversity of ecologic niches, these conditions were prerequisites of skeleton and shell acquisition by Early Cambrian animals, and as a consequence, accelerated morphologic evolution, increased diversity of taxons of different groups of animals.
\end{abstract}

Keywords: Cyanobacteria; Rhodophyta; Symbios; Skeleton; Biodiversity; Neoproterozoic; Cambrian; Siberian

\section{Introduction}

It is very important to clarify the role of cyanobacteria and algae in environment in the seas in connection with problems of ecosystem evolution and biologic diversity in the early Cambrian.

Early Precambrian microorganisms are most comparable with cyanobacteria in morphology, size and ecology. Whereas, some Precambrian microfossils can be attributed to algae regarding the same features. A. H. Knoll [1] cited the facts that, algae became very diverse around Mesoproterozoic-Neoproterozoic boundary (1000 million years).

\section{Materials}

Carbonate rocks of organogenic origin are widespread in Neoproterozoic and Lower Cambrian deposits of the Siberian platform. Samples of these rocks were collected by the author in order to detect microfossil in them since 1964. Collection has over ten thousand samples. Neoproterozoic calcified algae are very poorly studied due to safety, insufficient for the interpretation. For example, such calcified small (often microscopic) marine filamentous benthic macrophytes, as Dzhelindia Kolosov, 1970 and Chaptchaica Kolosov, 1975 [2,3] genera from Chenchin suite of the Late Proterozoic (Neoproterozoic) Baikal-Patom highland in Siberia, can be proved with difficulty that, they belong to algae.

\section{Methods}

Rock samples of organogenic origin were studied in thin sections using microscope. Different morphologic structures were identified. Their biologic nature as proved by confinement only to organic rocks, where the play rockforming role; by occurrence at the same stratigraphic level (Neoproterozoic); morphologic certainty and standing out in host carbonate rocks (predominantly in limestones); morphologic similarity to Paleozoic algae (for example, Filaria sporifera Korde, 1973; Nicholsonia involutum Korde, 1973; Kordephyton crinitum (Korde), 1955); colloform microstructure, typical for fossil organic remains [4].

\section{Results and Discussion}

Features, listed below, allow substantiating Dzhelindia and Chaptchaica belonging to rodofits:

1) Carbonate is deposited in cell walls. It is pelito- 


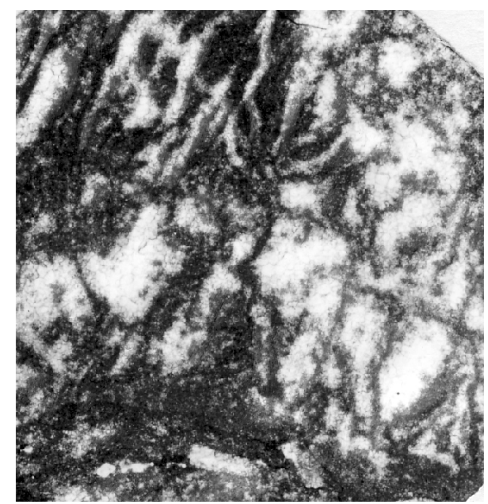

(a)

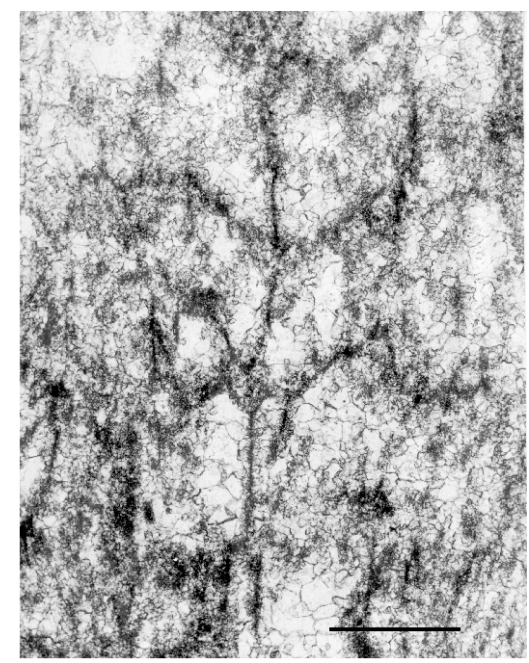

(b)

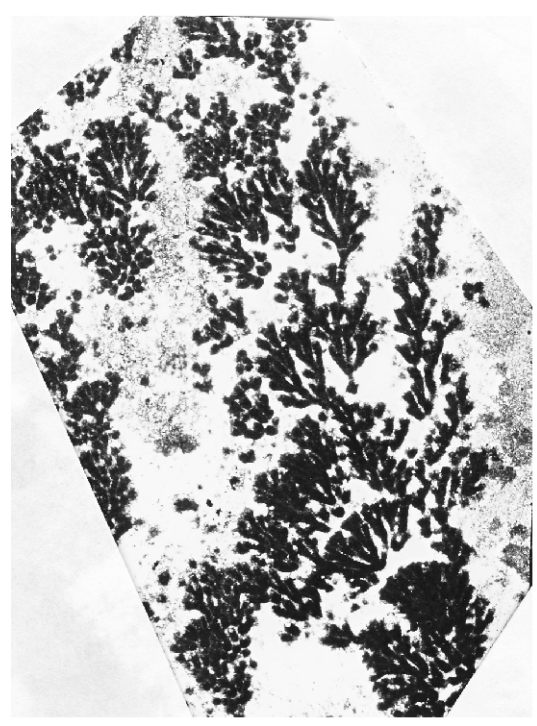

(c)

Figure 1. Neoproterozoic benthic algae (1000 - 541 million years ago) of Uplift in Siberia: (a) Dzhelindia diversa Kolosov, 1970; (b) Chaptchaica viva Kolosov, 1975. Early Cambrian (541 - 513 million years ago) in Siberia: (c) Rhodophyta of Epiphyton Bornemann, genus 1886. Scale length: for $A$ and $B-0.5 \mathrm{~mm}$; for $C-1 \mathrm{~mm}$. morphic, very fine textured, dark; it is syngenetic primary structure of algae carbonate. Dzhelindia Kolosov scanning electron microscope image clearly shows $[4$, p. 21 , Figure 2.14] that, particle $(2 \mathrm{mcm})$ of streamline form of calcium carbonate was deposited directly in frond.

2) Not only microscopic, but also macroscopic (filament length up to $1.2-1.6 \mathrm{~mm}$ ) fronds. Cambrian Epiphyton, belonging to rodofits, have species with bushes height of 1.0 - $1.6 \mathrm{~mm}$ [5]. Among modern rodofits Erythrotrichia carnea (Dillw.) J. Ag (Erithrotrichiacea family, Bangiales order, Bangiophyceae class) represents unbranched filaments length up to $1 \mathrm{~mm}$, thickness 11.0 $14.5 \mathrm{mcm}$, from one line of cells [6, p. 186].

3) It is known [7] that, complication of unilinear filament rodofits begins with appearance of big amount of short and abundantly branched side branches of organic growth. The same is observed in Neoproterozoic Dzhelindia.

4) Korde K. B. [8], researcher of Cambrian algae, identified new class Protofloridomorphophyceae Korde, 1973 in Rhodophyta division. Characterized Dzhelindia and Captchaica genera belong to taxon of the mentioned class regarding filiform, unilinear, sedentary, growing vertically, bushy frond, not differentiated into axial and crustal parts Dzhelindia Kolosov are most similar to Filaria Korde, 1973 and to Kordephyton Radugin et Strepanova, 1965, particularly to Kordephyton crinitum (Korde) [8, Table XIII, Figure 2]. Dzhelindia species are comparable in cell shape, type of filament branching, frond size to species of Sajania Vologdin, 1962 and Cambrina Korde, 1973 genera [8, Table XV, Figures 1, 2, 4; Figure 18].

5) Dzhelindia genus can be compared with some modern red algae. It is close to Goniotrichum Kützing genus (Goniotrichum Sjuja order, Bangiophyceae De Toni class) regarding unilinear, filament, irregularly branched, sedentary frond. It differs from Goniotrichum Kützing genus by lack of common thick membrane, covering all cells. This membrane of modern genus is jelly-like. But, regarding this feature, Goniotrichum can be compared with Precambrian Captchaica genus. The latter, probably, had thick jelly-like membrane. This assumption logically follows from presence of light aragonite, containing unilinear filament of cellular structure [4, p. 20, Figure 2.1.1]. In Captchaica thin section there is aragonite around filament, as a result of calcification, instead of thick jellylike membrane.

Dzhelindia Kolosov also looks like Audouinella Bory genus of Acrochaetiaceae (Hamel) Fritsch (Nemalionales Schmitz order) family. These are modern benthic microscopic red algae, consisting of unilinear, branched, creeping or rising up cellular filaments. Some representatives (for example, Audouinella Bory-Audouinella) of this family are fully or partially plunged into tissue of other algae or are settled on chitin shells of hydroids and bryo- 
zoans [6, pp. 204-205]. These filament red algae are almost the same rock-forming microorganisms, as cyanobacteria, building stromatolites [9, p. 362]. Dzhelindia Kolosov almost do not differ from Audouinella Bory in respect of microscopic size, structure of unilinear cells (up to $80 \mathrm{mcm}$ ), forming branching benthic filaments, location of reproductive organs (spermatangia) as clusters on side branches and rock-forming role. As Audouinella, Late Precambrian red algae in Ediacaran and Early Cambrian, possibly, were plunged into tissues of skeletonless animals. Cool spell at the turn of Cryogenian and Ediacaran could force many cyanobacteria, especially unicellular cyanobacteria and algae to hide in animal tissues. Red algae, inhabiting deeper than cyanobacteria, apparently, were not subjected to significant extinction during mentioned cool spell.

Captchaica Kolosov genus, as well as Dzhelindia Kolosov, can be considered representative of Cambrinales Korde, 1973 (rodofits) with respect to the structure of rising up fronds, comprising differently branched filaments, consisting of one line of cells, and location of reproductive organ on filament tips. Regarding branched filaments comprising rounded cells, forming thallus, surrounded by light carbonate (aragonite), Captchaica looks like Kadvoya Korde genus, identified in Cambrian [8, Table XVII, Figures 3-5; XVIII, Figures 1, 25]. Mentioned carbonate surroundings, apparently, is not accident. Probably, it shows that, algae during lifetime, was very mucous. Kadvoya diagnosis records this feature of the thallus.

Cell walls of modern rodofits are covered with mucus. Mucus of some forms can be up to $70 \%$ of dry weight of cellular wall. Many representatives are calcified [9]. Studying light wedge-shaped carbonate, closely associated with Captchaica viva Kolosov [3, sample. 206-68, Table XIV, Figures 1, 4] with the help of scanning electron microscope showed that, it is pierced with well-fined branched filaments with reproductive organs [4, Figure 2.1.2; reproductive organ is cup-shaped]. Captchaica, apparently, intensively emitted organic matter to the environment, which was mineralized and took the shape of particularly mineral formations as a result of diagenetic changes. Such forms of preservations are typical for some red algae. This one proofs that Captchaica Kolosov belongs to rodofits.

Modern Rhodophyta are mainly multicellular macroscopic organisms (from few centimeters to one meter in length) with complex morphologic structure and anatomy. In a less degree, they are represented by unicellular and colonial forms. Except for the above mentioned filament algae, there are unicellular and colonial forms among $\mathrm{Ne}-$ oproterozoic forms, i.e. similar to the most primitive rodofits, but in size more microscopic. As modern rodofits, Neoproterozoic and early Cambrian filament rodofits Dzhe-lindia, Captchaica, Epiphyton, Filaria, Cambrina et al., are marine, predominantly benthic.

The appearance in the Early Cambrian of more than 500 genera of marine invertebrates, of which most phyla and classes exist today, is the earliest example of biodiversity on Earth. As currently known, the Cambrian explosion in animal forms occurred in the eastern Siberian platform earlier than elsewhere in the world, which was related to their acquisition of a skeleton. What were the reasons for the formation of a skeleton in invertebrates? What was the role of red algae?

Mass acquisition of a skeleton or a shell by animals and, hence, their explosive evolution in the Early Cambrian in the eastern Siberian platform resulted from a combination of successive geological and biological factors and events in the Neoproterozoic-Early Cambrian. These are as follows:

1) According to the paleomagnetic data [10] in the second part of the Proterozoic and in the Cambrian, the Siberian platform was a separate continent located in the near-equatorial zone. The climate was warm, close to tropical, and the temperature of the water in the epicontinental sea basins ranged from +28 to $+32^{\circ} \mathrm{C}$. These were favorable conditions for the evolution of life.

2) The specific tectonics of the Siberian platform: the presence of the Aldan and Anabar anteclises with a NSstriking elongate uplifted zone between them. The warm shallow-water environment on the slopes of these and smaller positive structures was suitable for the growth of cyanobacteria and algae. In addition, the mentioned uplifted zone is cut by NS-trending deep faults through which primordial solutions penetrated into the seawater. Subsequently (in the Early Cambrian) the earliest reef ecosystem ("an island of intense vital activities" after F. J. Pettijohn) [11] originated in this zone.

3) Manifestations in the Neoproterozoic-Early Cambrian of rift and volcanic processes, including volcanism of basic (potassium) composition (from B. R. Shpount) [12]. Supply into the aquatic environment, along with potassium, of large volumes of carbon dioxide, calcium, phosphorus, magnesium, iron, sodium, nitrogen and other biogenic elements from depth was a further factor. The iron present in the water accelerated the process of photosynthesis, which led to increased biomass of algal communities.

4) The above-mentioned environmental conditions were quite favorable for the thriving of rock-forming microorganisms for over a billion years on the Siberian platform. In the Mesoproterozoic (1.6 - 1.0 Ga) these were mainly cyanobacteria, and in the Tonian and Cryogenian (1.0 $0.65 \mathrm{Ga}$ ) of the Neoproterozoic - chiefly benthic calcareous red algae (rhodophytes) of the genera Dzhelindia Kolosov, 1970, Chaptchaica Kolosov, 1970, etc. The mentioned Meso- and Neoproterozoic aquatic microorganisms produced large volumes of oxygen, organic mat- 
ter, and photosynthetically fixed calcium carbonate and phosphate buried within thick (a few hundreds of meters) strata; they performed environment-controlling and rockforming functions within the ecosystems of epicontinental basins. Along with carbon dioxide and water, involved in the photosynthetic process were biogenic elements such as nitrogen, phosphorus, potassium, magnesium, calcium and iron. Cyanobacteria and algae concentrated them in cells, colonies, and thalli.

5) Due to a rather long period of thriving of cyanobacteria and algae in the Precambrian, the amount of $\mathrm{CO}_{2}$ in the atmosphere and hydrosphere decreased. This caused a fall in temperature at the Neoproterozoic-Ediacaran boundary, which was followed by marine regression and mass mortality of cyanobacteria inhabiting warm water bodies in the littoral zone. By analogy with their recent counterparts, after a considerable decrease in the number of cyanobacteria in the Late Ediacaran and Cambrian one may assume an increasing role of: 1) bacteria that purified the water environment, fixed nitrogen (animals can assimilate nitrogen only in a fixed state), and, as opposed to cyanobacteria that reigned earlier, served as food for originating animals; 2) highly productive benthic red algae of the genera Floribundaphyton Kolosov, 1975, Epiphyton Bornemann 1886 etc. that enriched the sea-floor with oxygen. After the dead bodies of cyanobacteria fell to the seafloor to decay there, biogenic elements were mostly preserved in shallow-water seas due to reducers (bacteria), and continued to participate in biochemical cycling. As a result of the reduced activity of cyanobacteria, the waters of the Late Ediacaran-Early Cambrian epicontinental basins became even more numerously inhabited by benthic red algae (which survived the drop in temperature because they lived at a greater depth on the shelf than cyanobacteria) and bacteria, including iron bacteria; they also became more transparent, not oversaturated with organic matter and, hence, more oxygen-rich. The sunlight penetrated deep into the water. The enrichment of the bottom of sea basins within the Siberian platform in oxygen was favored, along with benthic algae, by the above-mentioned falls in temperature, which caused cooling of the water and origination of currents (as evidenced by oncolites present at many stratigraphic levels of the Upper Ediacaran and Early Cambrian). As a result of all the mentioned changes, a significant part of the bottom of sea basins became a photic zone. Opportunities for the origin of life in different forms were ample.

6) In the Late Ediacaran, a significant marine transgression (with cold seawater due to the fall in temperature) over the Precambrian, mainly organogenic (cyanobacterial and algal) limestones and dolomites began. The waters rich in free carbon dioxide (due to the mass extinction of cyanobacteria it was but little consumed) and organic matter got in contact with the mentioned cyano- bacterial and algal carbonate rocks (e.g. thick algal limestones outlined as the Chenchin Formation), dissolved them, and saturated with photosynthetically fixed calcium carbonate and phosphate, which were good material for the formation of a cover in calcareous algae and of a skeleton in animals.

7) As a result of transgression, the slopes of paleo-uplifts were covered with water. At the same time, epicontinental conditions continued to exist (as evidenced by abundant stromatolite rocks), which led to the formation of various ecological niches and potential biotopes.

8) The existence of soft-bodied metazoa in the coldwater zone of an open sea basin; the presence among them, in the late Ediacaran-early Cambrian in the northeastern Siberian platform, of microscopic and small (e.g. Kursovia Kolosov et Rudavskaya, 1984) evolutionary advanced, possibly genetically flexible, animals with an organic cover waiting for "a better time" to form a skeleton $[13,14]$.

9) A symbiosis between algae and animals is well known from many ecosystems. Algae supply animals with oxygen and consume the carbon dioxide they exhale. In the Early Cambrian, the smallest unicellular rhodophytes could settle down on animals with an organic cover, and physiologically (through the process of photosynthesis) alkalinize the environment causing $\mathrm{CaCO}_{3}$ precipitation. In 1996, Yu. T. Dyakov [15], Professor at Moscow University, demonstrated that recent symbiotic red algae, when settled on the surface of a host, inject their nuclei into the host's cells, thus displacing its own ones. Being both exosymbiotes and endosymbiotes of animals with an organic cover, they are likely to have promoted, through complex biochemical transformations in cells and optional heterotrophic metabolism, the biomineralization of the organic covers of metazoa. As a result, a great number of Early Cambrian skeletal animals came into being (mollusks, brachiopods, sponges, archaeocyaths etc.) [16].

Let's note one more possible way of using calcium carbonate by animals to form a skeleton. In the Early Cambrian, in the eastern Siberian platform, in a shallowwater sea basin, under the geochemical effect of organic compounds, in the water and in bottom precipitates, a rather dynamic calcium-carbonate equilibrium could change in such a way that here migration of photosynthetically fixed calcium carbonate from water into a precipitate and vice versa occurred reaching neither complete precipitation nor complete dissolution. This calcium carbonate could be intensely used in the Early Cambrian by algae (e.g. genera Epiphyton, Proaulopora, Subtifloria etc.) as well as by archaeocyaths and other animals to form a cover and a skeleton, respectively. As a result of the rapid reproduction of these organisms, the Earth's earliest reef ecosystem originated in the aforementioned 
zone. Subsequently it played an important role both in the formation of basins with different environmental conditions and in the evolution of life. With the formation of a calcareous cover in algae and a skeleton or a shell in animals they became protected from the effects of unfavorable factors (e.g. excess oxygen, being eaten by other organisms, destruction, cold, undesirable chemical elements). As a consequence, their rapid morphological evolution began, which in the Early Cambrian in the Siberian platform led to the earliest known explosion in biodiversity on Earth $[17,18]$.

\section{Conclusion}

Sharp increase in diversification of marine animals occurred in Late Cambrian of the Siberian platform. It was connected with the earliest assumption of skeleton and shell by many groups of animals on the Earth. Red algae, as well as abiotic factors, played a major role in this assumption. They enriched the bottom of epicontinental sea basins with oxygen, and contributed to biomineralization of metazoa organic covers.

\section{Acknowledgements}

The author is grateful to the authorities of Diamond and Precious Metal Geology Institute, Siberian Branch, Russian Academy of Sciences and support and constant attention of Laboratory of Stratigraphy and Paleontology colleagues.

\section{REFERENCES}

[1] A. H. Knoll, "Proterozoic and Early Cambrian Protists: Evidence for Accelerating Evolutionary Tempo (Proterozoic/Cambrian/Eukaryotes),"Proceedings of the National Academy of Sciences, Vol. 91, No. 15, 1994, pp. 67436750.

[2] P. N. Kolosov, "Upper Precambrian Organic Remains of the Southern Yakutia," In: A. K. Bobrov, Ed., Proterozoic and Cambrian Stratigraphy and Paleontology of the East Siberian Platform, Book Publisher, Yakutsk, 1970, pp. 57-70.

[3] P. N. Kolosov, "Stratigraphy of Upper Precambrian South of Yakutia," Nauka, Novosibirsk, 1975.
[4] P. N. Kolosov, "Late Precambrian Microfossils and Stratigraphy of Oil-and-Gas Bearing Deposits in the Eastern Siberian Platform," YF SO RAN, Yakutsk, 2003.

[5] K. B. Korde, "Cambrian Algae of the South-East Siberian Platform," AN SSSR Publisher, Moscow, 1961.

[6] A. D. Zinova, "Determinant of Green, Brown and Red Algae in the Southern Seas of the USSR," Science, Moscow-Leningrad, 1967.

[7] S. P. Vasser et al., "Algae. Reference Book," Naukova dumka, Kiev, 1989.

[8] K. B. Korde, “Cambrian Algae,” Nauka, Moscow, 1973.

[9] R. G. South and A. Whittick, "Introduction to Phycology," Mir, Moscow, 1990.

[10] J. L. Kirschvink and A. Yu. Rozanov, "Magnetostratigraphy of Lower Cambrian State from the Siberian Platform: A Paleomagnetic Pole and a Preliminary Polarity TimeScale," Geological Magazine, Vol. 121, No. 4, 1984, pp. 189-203.

[11] J. Pettijohn, "Sedimentary Rocks," 3rd Edition, Harper and Row, New York, Evanston, San Francisco, London, 1975, $752 \mathrm{p}$.

[12] B. R. Shpount, "Late Precambrian Riftogenesis of the Siberian Platform (Tectonic-Formation Analysis)," YF SO AN SSSR, Yakutsk, 1987.

[13] P. N. Kolosov, "Late Precambrian Microorganisms of the east Siberian Platform," YF SO AN SSSR, Yakutsk, 1984.

[14] P. N. Kolosov, "The Lena Pillars-An Outstanding Example Representing the Prime of Animal Evolution and a Place of Exceptional Natural Beauty," Bictik, Yakutsk, 2008.

[15] Y. T. Dyakov, "The Role of Endosimbiosis in Algae Evolution," Priroda, No. 6, 1996, pp. 24-36.

[16] P. N. Kolosov, "Is Calcification of Cambrian Archaeocyathean the Result of Symbiosis with Algae?" 10th International Palynological Congress, Abstracts, Nanjing, 2000, p. 85.

[17] S. A. Bowring, J. P. Grotzinger, C. E. Isachen, A. H. Knoll, S. M. Pelechaty and P. N. Kolosov, "Calibrating Rates of Early Cambrian Evolution," Science, Vol. 261, 1993, pp. 1293-1298.

[18] P. N. Kolosov, "Outstanding Universal Values of the Lena Pillars Nature Park," LAP LAMBERT Academic Publishing, Saarbrucken, 2013. 